\title{
Profile of vitamin-D deficiency patients in a tertiary care centre, Bhopal: causes and its implications in health
}

\author{
Samaiya $S^{1}$, Tiwari $S^{2}$, Singh $\mathbf{M}^{3}$, Saran $\mathbf{R}^{4}$ \\ ${ }^{1}$ Dr. Sachin Samaiya, Department of Orthopaedics, ${ }^{2}$ Mrs. Surya Tiwari, Department of Biochemistry, ${ }^{3}$ Dr. Manishi Singh, \\ Department of Biochemistry, ${ }^{4}$ Dr Rajat Saran, Department of Orthopedics; all authors are affiliated with Chirayu Medical \\ College and Hospital, Bhopal, MP, India.
}

Address for Correspondence:Mrs. Surya Tiwari, Email: surya28tiwari@gmail.com

\begin{abstract}
Introduction: Vitamin D deficiency is widespread in individuals irrespective of their age, gender, race and geography. The aim of this study was to assess the status of Vitamin D deficiency in various age group in the people visiting Chirayu Medical College and Hospital, Bhopal for their routine health check-up. Material and Methods: This study was done in the department of Orthopaedics and department of Biochemistry, Chirayu Medical College and Hospital Bhopal. The study comprised of the total of 100 subjects. Five millilitre of venous blood was collected from subjects in plain vials (red top tube) and the serum Vitamin D level was assessed by ELFA method using Biomeriuxminividas. Results: Among the 100 individuals studied in this study there was 66 Females and 34 Males. Among the study group studied it was found that approx. $25 \%$ of the total individuals studied are Vitamin D deficient i.e. having serum vitamin D level $<20 \mathrm{ng} / \mathrm{ml} .20 \%$ of the individuals in study group have insufficient vitamin D level i.e. between $20-29 \mathrm{ng} / \mathrm{ml} .44 \%$ of the total individuals studied have sufficient Vitamin D level (between $30-100 \mathrm{ng} / \mathrm{ml}$ ) in their sera but in this $44 \%$ individuals approx. $11 \%$ individuals have their serum vitamin D level in the borderline normal range i.e. between $30-40 \mathrm{ng} / \mathrm{ml}$. Conclusion: As Vitamin D deficiency affects all age groups, therefore, strategies such as increasing awareness among masses about adequate exposure to sunlight, rich dietary sources of vitamin D and fortification of foods with Vitamin D which are consumed by majority of Indian population irrespective of the socio-economic status can be adopted and implemented for prevention and control of Vitamin D deficiency throughout the nation.
\end{abstract}

Keywords: Vitamin D, Fortification, Socioeconomic status

\section{Introduction}

Vitamin D deficiency is pandemic, yet it is the most under-diagnosed and under-treated nutritional deficiency in the world [1].Vitamin D is endogenously synthesized in human beings from photo conversion of 7-dehydrocholestrol in the skin to cholecalciferol on exposure to ultraviolet radiation of sun. In a tropical country like India, where sunlight exposure is abundant, vitamin D deficiency seems unlikely.

However, as opposed to this, various studies have highlighted that $70-100 \%$ Indians in different age groups vitamin D insufficient or deficient [2]. The probable reasons of the wide spread vitamin $\mathrm{D}$ deficiency in Indians could be because of low dietary vitamin $\mathrm{D}$ intake, high fiber and phytate intake that depletes vitamin D levels [3], reduced exposure to sunlight [4], pollution [5]

Manuscript Received: $6^{\text {th }}$ March 2017

Reviewed: $16^{\text {th }}$ March 2017

Author Corrected: $24^{\text {th }}$ March 2017

Accepted for Publication: $31^{\text {st }}$ March 2017 or reduced exposure of skin to sun light because of cultural and traditional habits like "burkha" or "parda". The most well recognized function of $1,25(\mathrm{OH})_{2} \mathrm{D}$ involves regulation of calcium and phosphorus balance for bone mineralization and remodelling. Without adequate levels of $1,25(\mathrm{OH})_{2} \mathrm{D}$ in the bloodstream, dietary calcium cannot be absorbed. Low calcium levels lead to an increase in serum PTH concentration, which leads to increased tubular reclamation of calcium in kidneys and resorption from the skeleton at the cost of lowering bone density. In the long term this leads to weakened and brittle bones that break easily. Approximately $40 \%-60 \%$ of total skeletal mass at maturity is accumulated during childhood and adolescence. Rickets results from inadequate mineralization of growing bone. Thus it is a childhood disease and it is manifested as bone deformities, bone pain and weakness. Biochemical abnormalities consistently include hypophosphatemia, elevated alkaline phophatase 
levels and serum 25(OH)D levels are usually below 5 $\mathrm{ng} / \mathrm{mL}$. Chronic vitamin D deficiency in adults results in osteomalacia, osteoporosis, muscle weakness and increased risk of falls [6]. Epidemiological support for skeletal benefits of vitamin D is well known [7].

Assessment of vitamin D status of an individual is best reflected by measurement of circulating vitamin D metabolites. Only two metabolites, namely, 25hydroxyvitamin D [25(OH)D] and 1,25-dihydroxyvitamin $\mathrm{D}[1,25(\mathrm{OH}) 2 \mathrm{D}]$, have received the greatest attention in biochemical estimation of vitamin D. Of these, the need for measuring serum $1,25(\mathrm{OH}) 2 \mathrm{D}$ is limited. On the other hand, serum $25(\mathrm{OH}) \mathrm{D}$ provides the single best assessment of vitamin D status $25(\mathrm{OH}) \mathrm{D}$ as it has a halflife of about 3 weeks, making it the most suitable indicator of vitamin D status (4). The serum 25(OH)D cut-off $<50 \mathrm{nmol} / 1$ or $20 \mathrm{ng} / \mathrm{ml}$ may be associated with greater risk of non-skeletal chronic diseases [8].

The FAO/WHO expert Consultation [9] states that in most locations of the world between $42^{\circ} \mathrm{N}$ and $42^{\circ} \mathrm{S}$ latitude there is abundant sunshine. Exposure to sunlight is responsible for physiological production of Vitamin D endogenously in the skin from 7- dehydrocholesterol present in the subcutaneous fat. Thirty minutes of exposure of the skin over the arms and face to sunlight, without application of sunscreen, preferably between 10 am to $2 \mathrm{pm}$ (as maximum ultraviolet $\mathrm{B}$ rays are transmitted during this time) daily is required for adequate synthesis of vitamin D. [10].

Although vitamin D has been traditionally considered important for skeletal health, recent studies have reported that vitamin D also has beneficial effects on extra skeletal tissues [11]. Several studies have suggested possible links between vitamin D and cardiovascular disease risk [12].

The present study was done to assess the status of Vitamin $\mathrm{D}$ deficiency in various age groups in the people visiting Chirayu Medical College and Hospital, Bhopal for their routine health check-up.

\section{Material and Methods}

This study was done in the department of Orthopaedics and department of Biochemistry, Chirayu Medical College and Hospital Bhopal Bhopal. The study comprised a total of 100 subjects.

Five millilitre of venous blood was collected from subjects in plain vials (red top tube) and the serum Vitamin D level was assessed by ELFA method using Biomeriuxminividas.

\section{Result}

This study was undertaken to determine the levels of vitamin D deficiency in the general population visiting Chirayu Medical College and Hospital, Bhopal for their routine health check-up. Among the 100 individuals studied in this study there was 66 Females and 34 Males. As per the table 1, it was found that approx. 25\% of the total individuals studied are Vitamin D deficient i.e. having serum vitamin D level $<20 \mathrm{ng} / \mathrm{ml} .20 \%$ of the individuals in study group have insufficient vitamin D level i.e. between $20-29 \mathrm{ng} / \mathrm{ml}$. 44\% of the total individuals studied have sufficient Vitamin D level (between 30-100 ng/ml) in their sera but in this $44 \%$ individuals approx. $11 \%$ individuals have their serum vitamin $\mathrm{D}$ level in the borderline normal range i.e. between $30-40 \mathrm{ng} / \mathrm{ml}$. Gender based distribution of Vitamin D levels in study subjects is shown in table no. 2.

Table-1: Vitamin D Deficiency among the subjects in the study.

\begin{tabular}{|c|c|c|}
\hline Status & Vitamin d level & Prevelance \\
\hline Deficient & $<20 \mathrm{ng} / \mathrm{ml}$ & $25 \%$ \\
\hline Insufficient & $20-29 \mathrm{ng} / \mathrm{ml}$ & $20 \%$ \\
\hline Sufficient & $30-100 \mathrm{ng} / \mathrm{ml}$ & $44 \%$ \\
\hline
\end{tabular}

Table-2: Gender based levels of Vitamin D in the study subjects.

\begin{tabular}{|c|c|c|c|}
\hline Status & Vitamin d level & Prevelance in males & Prevelance in females \\
\hline Deficient & $<20 \mathrm{ng} / \mathrm{ml}$ & $7 \%$ & $18 \%$ \\
\hline Insufficient & $20-29 \mathrm{ng} / \mathrm{ml}$ & $6 \%$ & $14 \%$ \\
\hline Sufficient & $30-100 \mathrm{ng} / \mathrm{ml}$ & $17 \%$ & $27 \%$ \\
\hline
\end{tabular}




\section{Discussion}

It is now generally accepted that vitamin D deficiency is a worldwide health problem that affects not only musculoskeletal health but also a wide range of acute and chronic diseases. Vitamin D Deficiency is on a rise as a major public health problem in India. In the present study it was found that approx. $45 \%$ of the individuals are vitamin $\mathrm{D}$ deficient which is in accordance with the study conducted by Sachan A, et.al [13]. Skin complexion, poor sun exposure, vegetarian food habits and lower intake of vitamin D fortified foods could be attributed to the high prevalence of Vitamin D deficiency in India [14].

Vitamin D sufficiency by dietary intake is the only tenable solution for Indians. However, this solution itself has a barrage of problems. Most dietary sources of vitamin D have very low vitamin D content. Most of the food items rich in vitamin $\mathrm{D}$ are of animal origin. Most Indians are vegetarians. Commonly, a dietary source of vitamin D for vegetarians is milk, provided milk has been fortified with vitamin D. Milk is rarely fortified with vitamin D in India. The vitamin D content of unfortified milk is very low (2 IU/100 ml). Additionally, milk and milk products are unaffordable to the socioeconomically underprivileged. Another concern in India is the rampant dilution and/or adulteration of milk and milk products.

Low dietary intake of calcium in conjunction with vitamin $\mathrm{D}$ insufficiency is associated with secondary hyperparathyroidism (SHPT). SHPT is further exacerbated by induced destruction of $25(\mathrm{OH}) \mathrm{D}$ and $1,25(\mathrm{OH})_{2} \mathrm{D}$ by 24 hydroxylase [15]. 24 hydroxylase is the key enzyme of vitamin D catabolism and is regulated by $1,25(\mathrm{OH})_{2} \mathrm{D}, \mathrm{PTH}$ and FGF23 (Fibroblast Growth Factor 23) levels. FGF23 is a phosphate regulator. High serum phosphate levels increase production of FGF23 in bone osteocytes via the action of $1,25(\mathrm{OH})_{2} \mathrm{D}$. Subsequently, FGF23 reduces renal phosphate resorption, indirectly suppresses intestinal phosphate absorption and also suppresses PTH and $1,25(\mathrm{OH})_{2} \mathrm{D}$ synthesis. Overproduction of FGF23 can result in increased morbidity associated with vitamin D deficiency [16].

This regulatory mechanism may explain the low $25(\mathrm{OH}) \mathrm{D}$ levels in rural subjects on a high phytate and/or low calcium diet, despite plentiful sun exposure. Indian diet has high phytate content. Phytate is the principal storage form of phosphorus in many plant tissues, especially the bran portion of grains and other seeds. Phytate is indigestible to humans. Phytates chelate micronutrients such as calcium and iron, and thus reduce intestinal absorption of these nutrients. Benefits of sun exposure in rural subjects owing to an agrarian life were seen by significantly higher 25(OH)D levels [17]. However, possibly owing to high phytate content in diet, these levels were still insufficient in most individuals. Possibly, high phytate content in the diet of soldiers in northern India may have contributed to their vitamin D insufficiency, despite adequate sun exposure, nutrition and physical exercise [18].

In the scenario of inadequate calcium intake, vitamin D insufficiency and high phytate content in diet, environmental pollutants such as fluoride add insult to injury. Toxins like fluoride affect bone metabolism severely in the conjunction with inadequate calcium intake, especially in children [19].

A study in healthy adults who received either 400 or 2000 IU/d of vitamin $D_{3}$ for 3 months in winter reported that 291 genes were either up-regulated or downregulated. That these genes affected as many as 80 different metabolic pathways (from immune modulation to enhanced antioxidant activity) emphasizes the importance of improving the world's vitamin D status [20]. The observation that $1,25(\mathrm{OH})_{2} \mathrm{D}$ may also influence epigenetics provides additional support for the concept that there is no downside to increasing the vitamin D status of children and adults.

Vitamin D deficiency during pregnancy may adversely influence placental development and fetal programming.

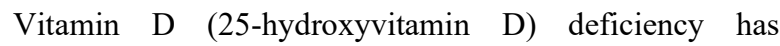
emerged as a public health focus in recent years for its contribution to adverse skeletal and extra-skeletal manifestations [21].

Race, age, body mass index (BMI), latitude, diet, sunlight exposure, and skin pigmentation are all factors influencing vitamin D status [22]. Vitamin D is important for reducing the risk of a variety of chronic illnesses. The identification of a Vitamin D receptor in most tissues and cells and the observation that a multitude of genes may be directly or indirectly regulated by $1,25(\mathrm{OH})_{2} \mathrm{D}$ have provided a rationale for the non-skeletal health benefits of vitamin D.

\section{Conclusion}

However, looking at the spectrum and high prevalence of Vitamin D deficiency in India, there is a need for further research to identify the major factors responsible for Vitamin D deficiency, despite of abundant sunshine available in the country. As Vitamin D deficiency affects all age groups, therefore, strategies such as increasing 


\section{Original Research Article}

awareness among masses about adequate exposure to sunlight, rich dietary sources of vitamin $\mathrm{D}$ and fortification of foods with Vitamin D which are consumed by majority of Indian population irrespective of the socioeconomic status can be adopted and implemented for prevention and control of Vitamin D deficiency throughout the nation.

Conflict of interest: None declared.

Funding: Nil, Permission from IRB: Yes

\section{References}

1. van Schoor NM, Lips P. Worldwide vitamin D status. Best Pract Res Clin Endocrinol Metab. 2011 Aug;25(4): 671-80. doi: 10.1016/j.beem.2011.06.007.

2. G R, Gupta A. Fortification of foods with vitamin D in India. Nutrients. 2014 Sep 12;6(9):3601-23. doi: 10.3390/ nu6093601.

3. Khadilkar AV. (2010) Vitamin D deficiency in Indian Adolescents. Indian Paediatr 47:756-757.

4. Ekbote VH, Khadilkar AV, Mughal MZ, Hanumante N, Sanwalka N, Khadilkar VV, Chiplonkar SA, Kant S, Ganacharya R. Sunlight exposure and development of rickets in Indian toddlers. Indian J Pediatr. 2010 Jan;77 (1):61-5. doi: 10.1007/s12098-009-0263-2.

5. Agarwal KS, Mughal MZ, Upadhyay P, Berry JL, Mawer EB, Puliyel JM. The impact of atmospheric pollution on vitamin D status of infants and toddlers in Delhi, India. Arch Dis Child. 2002 Aug;87(2):111-3.

6. Hazell TJ, DeGuire JR, Weiler HA. Vitamin D: an overview of its role in skeletal muscle physiology in children and adolescents. Nutr Rev. 2012 Sep;70(9):52033. doi: 10.1111/j.1753-4887.2012.00510.x.

7. Thacher TD, Clarke BL. Vitamin D insufficiency. Mayo Clin Proc. 2011 Jan;86(1):50-60. doi: 10.4065/ mcp.2010.0567.

8. Zittermann A, Schleithoff SS, Tenderich G, Berthold HK, Körfer R, Stehle P. Low vitamin D status: a contributing factor in the pathogenesis of congestive heart failure? J Am Coll Cardiol. 2003 Jan 1;41(1):105-12.

9. Report of Joint FAO/ WHO expert Consultation on vitamin and mineral requirement in human nutrition: bangkok 1998. Second Edition FAO Rome,2004.

10. Londhey V. Vitamin D deficiency: Indian scenario. J Assoc Physicians India. 2011 Nov;59:695-6.
11. Holick MF. Vitamin D deficiency. N Engl J Med. 2007 Jul 19;357(3):266-81.

12. Kendrick J, Targher G, Smits G, Chonchol M. 25Hydroxyvitamin D deficiency is independently associated with cardiovascular disease in the Third National Health and Nutrition Examination Survey. Atherosclerosis. 2009 Jul;205(1):255-60. doi: 10.1016/j.atherosclerosis.2008. 10.033. Epub 2008 Nov 11.

13. Sachan A, Gupta R, Das V, Agarwal A, Awasthi PK, Bhatia V. High prevalence of vitamin D deficiency among pregnant women and their newborns in northern India. Am J Clin Nutr. 2005 May;81(5):1060-4.

14. Goswami R, Gupta N, Goswami D, Marwaha RK, Tandon N, Kochupillai N. Prevalence and significance of low 25-hydroxyvitamin D concentrations in healthy subjects in Delhi. Am J Clin Nutr. 2000 Aug;72(2):472-5.

15. Jones G, Prosser DE, Kaufmann M. 25Hydroxyvitamin D-24-hydroxylase (CYP24A1): its important role in the degradation of vitamin D. Arch Biochem Biophys. 2012 Jul 1;523(1):9-18. doi: 10.1016/j. abb.2011.11.003. Epub 2011 Nov 12.

16. Liao E. FGF23 associated bone diseases. Front Med. 2013 Mar;7(1):65-80. doi: 10.1007/s11684-013-0254-6. Epub 2013 Mar 9.

17. Harinarayan CV, Ramalakshmi T, Venkataprasad U. High prevalence of low dietary calcium and low vitamin D status in healthy south Indians. Asia Pac J Clin Nutr. 2004;13(4):359-64.

18. Tandon N, Marwaha RK, Kalra S, Gupta N, Dudha A, Kochupillai N. Bone mineral parameters in healthy young Indian adults with optimal vitamin D availability. Natl Med J India. 2003 Nov-Dec;16(6):298-302.

19. Khandare AL, Harikumar R, Sivakumar B. Severe bone deformities in young children from vitamin $\mathrm{D}$ deficiency and fluorosis in Bihar-India. Calcif Tissue Int. 2005 Jun;76(6):412-8. Epub 2005 May 19.

20. Hossein-nezhad A, Spira A, Holick MF. Influence of vitamin D status and vitamin D3 supplementation on genome wide expression of white blood cells: a randomized double-blind clinical trial. PLoS One. 2013;8(3):e58725. doi: 10.1371/journal.pone.0058725. Epub 2013 Mar 20.

21. Holick MF. Vitamin D deficiency. N Engl J Med. 2007 Jul 19;357(3):266-81.

Available online at: www.surgicalreview.in 22 | P a g e 
Original Research Article

22. Mithal A, Wahl DA, Bonjour JP, Burckhardt P, Dawson-Hughes B, Eisman JA, El-Hajj Fuleihan G, Josse RG, Lips P, Morales-Torres J; IOF Committee of Scientific Advisors (CSA) Nutrition Working Group.
Global vitamin D status and determinants of hypovitaminosis D. Osteoporos Int. 2009 Nov; 20 (11): 1807-20. doi: 10.1007/s00198-009-0954-6. Epub 2009 Jun 19.

\section{How to cite this article?}

Samaiya S, Tiwari S, Singh M, Saran R. Profile of vitamin-D deficiency patients in a tertiary care centre, Bhopal: causes and its implications in health. Int J surg Orthopedics.2017;3(1):19-23.doi:10.17511/ijoso.2017.i01.04. 